\title{
Article \\ Phenomenology of Exclusion: Capturing the Everyday Thresholds of Belonging
}

\author{
Annika Lems \\ Max Planck Institute for Social Anthropology, 06114 Halle Saale, Germany; E-Mail: lems@eth.mpg.de
}

Submitted: 25 May 2020 | Accepted: 8 July 2020 | Published: 19 November 2020

\begin{abstract}
In this article I critically interrogate the ways researchers produce knowledge about the making and unmaking of borders. I do so by focusing on social processes of boundary-drawing that have dramatically intensified since the 2015 summer of displacements in Europe. I think through some of the methodological possibilities and conundrums that arise if we try to make visible the unarticulated social conventions underlying the everyday thresholds of belonging that determine who is permitted in, and who has to remain outside, the affective socio-political space of societies. By drawing on my own research experiences, I show why methodologies aimed at lending marginalized people a voice often fail to capture the voiceless, silent nature of these boundary-drawing practices. I suggest that in order to bring the invisible barbed wires permeating societies into the open, we need to develop phenomenologies of everyday exclusionary practices, or 'cultures of unwelcome.' Through my ethnographic encounters with marginalized refugee youth and individuals who believe that the influx of refugees is a threat to their values and ways of life, I argue for more nuanced research methodologies that allow us to better capture the everyday social processes underlying acts of boundary-drawing. I suggest that approaching border work as an intersubjective, worldly phenomenon involves paying attention to the experiences of individuals who find themselves pushed to the margins of society, and to those who actively participate in keeping people and groups marked as other locked out.
\end{abstract}

\section{Keywords}

border work; ethnography; exclusion; phenomenology; radicalization; refugee crisis; right-wing activism

\section{Issue}

This article is part of the issue "Method as Border: Articulating 'Inclusion/Exclusion' as an Academic Concern in Migration and Border Research in Europe" edited by Kolar Aparna (Radboud University, The Netherlands), Joris Schapendonk (Radboud University, The Netherlands) and Cesar Merlín-Escorza (Radboud University, The Netherlands).

(C) 2020 by the author; licensee Cogitatio (Lisbon, Portugal). This article is licensed under a Creative Commons Attribution 4.0 International License (CC BY).

\section{Introduction}

Against the backdrop of the dramatic intensification of Europe's closed-door policies in recent years, social scientists are struggling to keep pace with the multiple borders they produce. Contrary to dominant explanatory patterns these 'border spectacles' (De Genova, 2013) did not appear out of the blue or as the result of a 'refugee crisis' overwhelming European nation states. They have been in the making at least since the 1990s, when wealthy nation states started to fence themselves off against unwanted migrants from countries struck by poverty and postcolonial conflicts (Chimni, 2000). Yet, the ambiguous nature of border work- "the messy, contested and often intensely social" (Reeves, 2014, p. 6; also see Rumford, 2008) work involved in the making and unmaking of borders-has become particularly visible in the aftermath of the 2015 summer of displacements, when hundreds of thousands of refugees made their way to Europe. The narrative of a refugee crisis threatening the social and cultural order of things in Europe has been used to justify the multiplication of boundary-drawing practices. It has produced highly ambiguous new social realities for migrants and refugees who find their mobility cut short, whilst simultaneously being kept in continuous loops of commotion (Lems, 2019). 
The dilemma of how to methodologically approach Europe's "lethal border" regime (Perl, 2018, p. 86) and the paradoxes it produces has gained considerable scholarly attention in recent years. It has instigated important debates about the slipperiness of ethnographic research in continuously fluctuating settings (Schapendonk, 2020), the role of agency and autonomy in migrants' attempts to trick and overcome violent border control mechanisms (De Genova, 2017), and the danger of reinforcing the logic of crisis border regimes operate on through social science research practices (Cabot, 2019; Ramsay, 2019). Importantly, some scholars have pointed out that the ambiguities of contemporary border work cannot be reduced to the geophysical locale of the border (Reeves, 2014; Sossi, 2006). The European Union's tactics of fortressing itself against undesired people has created a situation where migrants are confronted with Europe's borders long before they actually set foot on its territory. I would add that these borders also do not end once refugees and migrants reach European soil. The increased importance of ambiguous social markers such as migrants' 'integration' efforts (Rytter, 2019) show that Europe's geopolitical borders make way for more opaque bordering practices. The borders I am aiming at do not mark out legal or national territories but inner, affectively charged terrains of belonging.

Yuval-Davis, Wemyss, and Cassidy (2018) coined the term 'everyday bordering' to describe how border control practices come to be transferred from the external physical terrain of the border into the internal social domain of everyday life, thereby turning ordinary figures of public life such as teachers or doctors into extended border guards. In conversation with this work, Strasser and Tibet (2020) have noted that while everyday bordering practices cannot be reduced to the locale of the border, they are also not limited to the institutional sphere. Instead, we need to develop the analytical means to assess the ways such practices are anchored in the realm of the everyday and folded into social relationships. What is needed, then, is an epistemological move beyond the strong fixation on policies, legal frameworks and hegemonic discourses that has marked much research on bordering practices. Even though the macro-dynamics fueling border work are undoubtedly of crucial importance, they cannot explain how borders are set up and maintained on a vernacular, social basis.

In this article I will explore some of the methodological possibilities and conundrums that arise if we shift the analytical focus from refugee studies to practices of exclusion. Based on my previous and on-going research, I will show how I have come to the conviction that if we are to gain a more nuanced understanding of the backlash against inclusive ideas of belonging currently sweeping through liberal democracies, we need to pay serious ethnographic attention to the formation, maintenance and defense of what Stoler (2018) describes as 'interior frontiers.' They are the vernacular thresholds of belonging that create unspoken distinctions between self and other, familiar and alien, or inside and outside. What makes interior frontiers so hard to grasp with conventional tools of social science research is the fact that they often do not make themselves apparent through open acts of boundary-drawing (Lamont \& Molnar, 2002), but involve boundaries that are drawn in much quieter, less obvious ways. Yet, even though interior frontiers are less visible than external ones, they hold a great degree of power over the lifeworlds of individuals, as they delineate who is allowed in and who is to be kept out of the 'communities of value' (Anderson, 2015) making up the affective socio-political space of societies. The kinds of borders I am aiming at cannot be traversed through official procedures or legally binding documents. Stoler $(2018$, p. 3) emphasizes that the effectiveness of interior frontiers stems precisely from the fact that they are not delineated by barbed wires, "but by unarticulated and often inaccessible conventions."

In this article I think through the methodological steps it might take to make visible the unarticulated social conventions underwriting interior frontiers. I suggest that in order to bring the invisible barbed wires permeating contemporary European societies into the open, we need to develop phenomenologies of exclusion. Often described as the scientific study of experience, phenomenology aims to understand phenomena from how they are experienced and made sense of in the everyday, prior to theoretical abstraction. By generating theorisations from the lived experiences of particular human beings, phenomenologically oriented ethnographers aim to move beyond monolithic concepts, such as 'the social' or 'the cultural,' and towards the particularity of intersubjective, everyday processes of meaning-making (Lems, 2018). Adopting a phenomenological approach is to "declare an intellectual commitment to engage directly with lived situations, in all their empirical diversity, intersubjective complexity and open-endedness" (Jackson, 2019, p. 150). In the context of border methods, it entails turning the focus on the intersubjective dimension of exclusion-to approach it as a lived social phenomenon that cannot be understood detached from the habitual ways people are oriented toward the world. Due to its closeness to people's everyday processes of meaningmaking, ethnographic research has a crucial role to play in gaining more nuanced knowledge about the intersubjective nature of border work. However, as I turn to my own research experiences it becomes clear that intersubjectivity should not be misunderstood as a synonym for empathy, harmony or shared experience (Jackson, 1998, p. 4). Approaching border work as an intersubjective, worldly phenomenon involves paying attention to the experiences of both the individuals who find themselves placed outside the interior frontiers of belonging, and those who actively participate in keeping people and groups marked as other locked out. A phenomenological approach to exclusion thus confronts the researcher with a set of ethical and methodological dilemmas that are not easy to overcome. 
While there is a long and established tradition in ethnographic research that aims to uncover the experiences or 'voices' of ordinary people, the focus has been mainly on the concerns of marginalized communities or individuals. Propelled by the incentive of democratizing research processes, ideas of friendship and dialogue have turned into guiding principles of ethnographic research endeavours, leading to the implicit assumption that in order to gain access to their informants' experiences, ethnographers need to share their world views (Teitelbaum, 2019). The phenomenological approach to exclusion I aim to sketch in this article destabilizes the ideal of scholar-informant solidarity underwriting the paradigm of voice. Through examples from my ethnographic encounters with both marginalized refugee communities and individuals who actively engage in exclusionary practices, I will sketch some of the problems and pitfalls of research methodologies that aim to uncover participants' voices. In a first step, I will give some insights into the dynamics of my research with unaccompanied refugee youth in Switzerland. I will spell out the traps that researchers might fall into if they uncritically use voice as a methodology to expose the inner workings of border regimes. By drawing on my own research experiences, I will show how ethnographic research methodologies aimed at lending marginalized youth a voice failed to capture the voiceless, silent nature of the interior frontiers the young people found themselves up against. By shedding light on some of the ways these frontiers made themselves noticeable, I will argue for more nuanced research methodologies that allow us to better capture the everyday border work through which certain groups and individuals come to be pushed to the margins of society. In a second step I will show why I believe that this methodological repertoire should also include a more thorough engagement with the experiences, stories and perspectives of people who actively participate in this border work.

\section{The Paradox of Voice}

My conviction that we have to develop a more versatile repertoire of research methods to be able to better capture the tacit and messy nature of border work did not occur in a theoretical void. The need for a phenomenology of exclusion grew directly from the conversations I had with a group of young refugees who had applied for asylum in Switzerland. All of the young people had arrived in the wake of the 2015 summer of displacements and were categorized as unaccompanied minors. As part of an ethnographic research project I followed the everyday pathways of these eight youth from Eritrea, Guinea and Somalia and their extended circle of friends for close to two years. The project aimed to understand the role of education in young people's migration trajectories and study the possibilities and hurdles they encountered in the Swiss education system. Beside these objectives, my research was driven by an interest in the complex yet pro- found role of education in the youth's existential strivings for recognition and belonging in an unequal world.

When I designed my research approach I was eager to deploy methods that would enable me to shed light on the young people's own perspectives and experiencesto explore tools that would encourage them to become ethnographers of their own lifeworlds (Oester \& Brunner, 2015). My interest in developing such an extended, 'experience-near' (Wikan, 1991) angle on education was partially informed by debates on child-centred approaches in ethnographic youth and childhood studies that urge scholars to recognize young people as important social actors whose perspectives need to be engaged with directly in research (Franks, 2011; James, 2007). It was also informed by the work of refugee research scholars who call for the use of creative and collaborative research tools (Alexandra, 2008; Nunn, 2017; O'Neill, 2011) to overcome homogenizing portrayals of refugees as voiceless, apolitical and ahistorical victims (Malkki, 1996). Against the backdrop of these thoughts, I looked for methods of participatory observation that felt more participatory and less like observation. I was given the opportunity to do so by joining the radio project that Thomas, a social pedagogue, had established in one of the homes for unaccompanied minors in the Canton of Bern. While assisting the pedagogue with the group's activities, I was able to work with the young participants on stories that were aired once a month on an independent youth radio station. Once we had established trustful relationships and the youth had acquainted themselves with my double role as a participant and researcher, I extended our meetings beyond the radio setting. After gaining permission from the school, I also started participating in the reception classes for unaccompanied refugee youth that most of the radio group's participants were attending.

My interest in research methodologies that would make the young refugees' voices heard resonated with the ambitions of Thomas. He had initiated the radio project with the idea that the young people would use the radio stories as a tool for reflecting on the reality of being an unaccompanied minor in Switzerland-an outcome he believed to not just be educative for the young refugees themselves but also for the Swiss audience listening to their stories. Not dissimilar to my own interest in dialogical research tools, Thomas was influenced by narrative youth work approaches. He believed in the emancipatory potential of storytelling and hoped that the radio project would create an arena for the young people to express their voices. As I started to work with the radio group, however, I came to realize that the hopes for personal and societal transformation underlying the paradigm of voice needed critical unpacking. This insight dawned on me during one of our first meetings, when Thomas tried to convince the radio group to participate in an event on the plight of unaccompanied minors organized by a charitable organisation in Bern. His idea was for young people to participate and produce a radio 
story reflecting on how Swiss people represented them. When introducing the idea to the group, the reaction was anything but enthusiastic. Jamila, a sixteen-years-old girl from Eritrea, rolled her eyes and sighed. "Oh no, that's boring," she said. I asked her to explain why she thought it was boring: "Always all these refugee stories-in the media and everywhere I go. It's too much." It became clear that the young people did not perceive the public arena the radio project created as a welcome opportunity. Instead, they experienced the pressure to dwell on their personal stories as a further burden, adding yet another expectation to their already heavily monitored lives as dependents of the Swiss state. "I cannot stop and look back," seventeen years-old Thierno from Guinea explained one afternoon, when I prompted him to talk about his migration story. He added: "I come to the radio group because it helps me forget."

When asked to tell their own stories, the young people frequently fell back on rehearsed asylum tales, streamlined to fit with the narratives that Swiss immigration authorities and social workers wanted to hear from them. Given the sense of suspicion the young people were confronted with in the Swiss asylum landscape, where they constantly had to over-perform their deservingness as child refugees, the ability to tell a good and acceptable story of themselves took priority over expressing their intimate stories. The radio pieces we produced were therefore a far cry from the compelling narratives Thomas and I had expected to emerge from the project. The participants found the amount of time and effort required to create a good radio story in a language that was still new to them exhausting, and instead opted for short music-driven pieces that did not require them to talk much. They came to the radio project mainly because it offered a welcome escape from the anxiety and boredom marking daily life in the overcrowded homes. After a few months, the young people lost their interest in producing radio stories altogether. They increasingly started to use the realms of the radio group gatherings to discuss stories they would like to make in the future, rather than actually making them. These discussions about fictional stories evolved into the discussion of themes that were of importance to them in general-and the radio project gradually transformed into a form of hangout space.

At a first glance the radio project did not seem to offer many insights into the young people's lifeworlds. Contrary to my own and Thomas' expectations, it had not instigated a process of personal transformation in the participants, enabling them to voice their innermost thoughts and concerns. Yet, the projects' conversion from a collaborative storytelling endeavour into a more private social space allowed for different, more complex stories to appear. In doing so, the project's failure paradoxically flung open a window to understanding the young people's struggles for emplacement in Swiss society. This insight, however, did not grow magically from the stories the young people produced in the radio project. This window only opened once I scrutinised my assumption that if given a mediating tool the youth would happily speak out about their experiences of displacement. By joining the youth in their everyday routes and routines I learned to decipher their refusal to tell their stories. Rather than uncovering the young people's voices, I came to see the importance of developing ethnographic tools that enable us to detect and examine the voiceless traces violent acts of boundary drawing leave behind in individuals.

\section{Capturing the Frontiers of Belonging}

In many ways, the young people I worked with were successful border workers in their own right. Driven by the hope for a better future, they had taken lifechanging decisions on their own and embarked on extremely challenging journeys at a very young age. The youth were amongst the lucky few who had managed to overcome violent migration control measures, cross the Mediterranean on leaky boats and escape border patrols to make it to Switzerland, one of the wealthiest countries in the world with an excellent public education system. Classified as unaccompanied minors, they enjoyed a special protection status which gave them privileged access to education, housing and legal aid. But when I extended my research focus beyond the radio project, I came to see that the young people did not regard these advantages to be door openers to Swiss society. Instead, they experienced the plethora of expectations directed at them as a continuation of the bordering practices they had been confronted with throughout their migration journeys.

As I accompanied the youths into the refugee reception classes they attended, caught up with them in our weekly radio group meetings or joined them in daily activities, I came to observe their continuous acts of learning and perfecting the social and linguistic codes that would enable them to be recognized as equal by their Swiss counterparts. It included mimicking their expressions, learning when to be quiet in order not to stick out, and internalizing unwritten rules about how to, or not to, move about in public spaces. Yet, I also came to observe how these placemaking efforts were continuously unsettled by the defensive attitude the young people encountered on the side of people who felt that they should not be allowed to lay claim to this place. The outlines of these frontiers of belonging first became visible to me through the interactions I observed in the classroom. As I sat in on lessons in the reception classes the young people went to, I was surprised about the negative, deficit-centred stance the pedagogues showed towards their refugee students, even though most of them self-identified as open-minded and politically progressive educators. Rather than empowering the young people and building on their strengths and motivations, the teachers continuously emphasized their deficiencies, which, they argued, made it impossible for their students to make the jump to mainstream schooling any time soon. While the so-called integration classes the 
youth attended presented themselves as inclusive education programs aimed at creating pathways for unaccompanied refugee youth to participate in Swiss society, they created an insurmountable number of obstacles for them (Lems, 2020). These obstacles did not show in the form of open displays of rejection. They were often hidden behind a language of care-for example when teachers argued that in refusing to support excellent students' promotion from the segregated refugee-only class into a secondary school they were protecting them because they were not ready to fully participate in Swiss society, or, when young people who had successfully obtained an apprenticeship were talked out of taking it up on the basis that they were emotionally and academically not ready for such a large commitment. Over time cracks started to appear in the veneer of care. As the vast majority of the students failed to be promoted from the segregated classes into mainstream education, it became increasingly obvious that the state of 'readiness' the teachers aimed for was unachievable.

My conversations with the pedagogues revealed that they were deeply concerned about the question of how European societies were going to deal with the socioeconomic consequences of the 'refugee crisis.' They understood their roles as social pedagogues as gatekeepers of Swiss society. Through their pedagogical work they tried to achieve a transformation in the refugee youth that was not just important for their individual futures, but for the future of Swiss society at large. The pedagogues were convinced that their main task was to help the young people integrate into a system of values which, they believed, was deeply alien to them. Yet as I sat in on the lessons it became evident that the process of 'integration' the teachers were aiming at was a one-way street. While it required the full submersion of the young people into Swiss society, it did not require Swiss people to show any flexibility in accommodating the ideas or habits the refugee youth had brought along. The problem with this asymmetrical model of integration is that even if refugees do their best to accept the wishes of their hosts and blend in, this does not preclude the emergence of new barriers. Rytter (2019, p. 688) therefore describes integration as a Sisyphean task: "Actual integration seems to be impossible because there are always new fences to climb and new stones to roll up the mountain."

Whilst easily overlooked because of their commonplace appearance, I suggest that the conceptions of race and cultural difference reverberating through these everyday acts of boundary-drawing need to be understood as the fundaments and catalysts of interior frontiers. When piercing through the surface of the seemingly benevolent language of care and integration permeating the school settings the young people were moving through, historically ingrained narratives of Swiss cultural supremacy come to the fore (Fischer-Tine \& Purtschert, 2015; Schinkel, 2018). They link into a deep-seated fear of Überfremdung (over-foreignization), which has molded the country' migration policies from the nineteenth century onwards (Wicker, 2009, p. 26). This fear is based on the discursive construction of the figure of the immoral/undeserving foreigner who is leading a good life at the expense of the Swiss taxpayer (D'Amato, 2012, p. 99). These historical and discursive configurations form the subtext of contemporary integration policies in Switzerland, where the debate has gradually moved from the right of refugees and migrants to be included in Swiss society to a demand that they must integrate (Piñeiro, 2015, pp. 22-24). What resonates in all these debates is the fear of an imminent crisis: A deepseated fear that if cultural difference is tolerated, this will inevitably lead to the collapse of Swiss traditions and values and to the disintegration of the country's wealth.

Against the backdrop of this political landscape, the young people I worked with were struggling with a deep and utter feeling of being-out-of-place. This sense of being-out-of-place is not due to the inherent impossibility of belonging refugees have as a result of their experiences of displacement. In a socio-political climate where migrant bodies are marked as problem cases in need of integration, control or expulsion, refugees are actively kept from laying claim to places - they are pushed into a feeling of being-out-of-place. It is precisely these "deep tectonic shifts" in liberal democratic societies that Stoler $(2018$, p. 1) aims to capture with the analytical metaphor of the interior frontier. Influenced by the work of Fichte and Balibar, she deploys 'interior frontier' as an analytical lens that helps her understand "what sorts of sensibilities get recruited to produce hardening distinctions between who is 'us' and who is constructed as (irrevocably) 'them"' (Stoler, 2018, p. 2). It urges scholars to look for different means of responding to the cementing of inequalities across the world and capture processes of social exclusion that often remain invisible with the methodological tools at hand (Stoler, 2018, p. 1). To bring the phenomenological quality of interior frontiers into the open, it does therefore not suffice to deploy a bird's eye view. Stoler (2018, p. 2) suggests that because of their opaqueness they require a "multiplex optic," which is at once intimate and proximate.

Similarly, the interior frontiers of belonging the refugee youth were up against did not become visible to me by simply giving the youth a chance to release their voices. What makes these frontiers so difficult to grasp with narrative methodologies is that their modus operandi is based on a contingent, non-spoken form of border work. It is therefore often precisely in the silences, muttered utterances, or half-told stories that interior frontiers become visible. It was only after I opened up my methodological repertoire that I was able to take note of the fragmentary and non-linear ways the young people had been sharing their experiences of exclusion all the while. This included the brief moments when the youth reflected on the general feeling of unwelcomeness that they were exposed to in their everyday encounters with Swiss people. It shimmered through the question that Samuel, a seventeen years-old Eritrean posed one after- 
noon during a radio group gathering: "Look, I can stay here, and I am happy to work and learn and do everything they [the Swiss] want me to do. But do they really want me here?" And it spoke through the reaction of his friend Meron, who asked me: "It's true, they [the Swiss] don't want us here, right?"

Often, interior frontiers only became graspable through small, intangible actions signalling to the youth that they did not have a right to belong to this place. They included experiences on public transport, when people refused to take a seat next to them, interactions with bus drivers who refused to stop when it was 'only' refugee kids waiting at the village bus station next to the home for unaccompanied minors, or the habitual ways people stared at them when they entered shops or public spaces. These everyday acts of border work hardly ever involved openly exclusionary behaviour. Without ever saying a word, however, they managed to deeply unsettle the young people, replacing the hopeful expectations many of them had attached to their educational opportunities in Switzerland with a hopeless attitude of 'I cannot' (Ahmed, 2007, p. 161). Whilst refusing to be verbalized, such embodied, habitual appearances of exclusion should not be ignored or written off as inconclusive. They reveal something essential about the ways people who do not possess the social, emotional or political capital to turn their experiences into a coherent storyline, make sense of the unequal world they find themselves thrown into.

The ability to render one's experiences into a plot is not self-explanatory. Das (1995, p. 22) argues that for people whose lives are marked by violent events it becomes extremely difficult to formulate the conditions for their suffering. She notes that rather than trying to establish a meaning in suffering, we need to pay attention to the victims' own understandings of the world, which are often accidental, chaotic and contingent in nature. Similarly, a phenomenological approach to exclusion cannot reduce its focus on extracting the agentive voices of the marginalized. It needs to pay serious ethnographic attention to the muted and fragmented experiences that are the outcome of violent border regimes and that may render the idea of speaking up or, indeed, speaking at all, impossible. Regarding such voiceless traces as part and parcel of our methodological repertoire allows glimpses of the opaque power of interior frontiers. They allow us to expose their corporeal character, how they not only determine who or what is to be regarded as external to the polity, but also how they manage to make people feel strange. They allow us to show how societal discourses manage to inscribe themselves onto the bodies of individuals and get woven into the fabric of the everyday (Das, 1995, p. 22).

\section{Everyday Bricklayers}

In my previous research I came to see the grave impact of everyday border work on the lives of young refugees.
The interior frontiers they found themselves confronted with did not just affect their movements through public spaces. They formed road blocks to key arenas of futuremaking, forcing them into desperate existential balancing acts. The general atmosphere of hostility and unwelcome the young refugees were grappling with confronted me with the need to develop methodological tools that would allow me to gain a deeper understanding of the social processes underlying such everyday acts of exclusion. Yet, while exposing the voiceless traces of border work allowed me to shed light on the effects of interior frontiers, this approach did not enable me to understand exclusion in its full intersubjective complexity. In order to gain a deeper understanding of the building blocks and building-practices underlying them, I therefore needed to extend my ethnographic focus yet again. To stay with the conceptual metaphor of the interior frontier, I needed to devote more attention to the everyday practices of its bricklayers.

The research group I am currently heading, Everyday Histories of Global Change, aims to do precisely this. I have shifted my empirical focus from refugees to the lifeworlds of people who perceive refugees as a threat to their values and ways of life. I try to establish how people actively participating in everyday border work experience and make sense of notions such as tradition, belonging and estrangement-key building blocks in the creation of interior frontiers. Together with my research team I do so by paying ethnographic attention to genealogies of exclusionary practices in municipalities in the Swiss, Austrian, and Italian Alps, that are characterized by long histories of global interconnection on the one hand, and support for reactionary political movements on the other. Throughout the centuries the German-speaking Alpine region has interchangeably been depicted as Europe's rural, backward periphery or as the last locus of authentic values and traditions. It has been marked by fractious relationships with urban centres of power and a historically engrained opposition to the decisions being ordered from above. By zooming in on the ways the inhabitants of these communities engage with the past, we try to come to a deeper understanding of the role local, everyday engagements with history play in determining who is permitted entrance to, and who is to remain outside of, interior frontiers of belonging. The research group is guided by the question of how people actively negotiate questions of place attachment and belonging, and looks at the social work that local, everyday understandings of history do: When do they become a means for creating social closeness and when are they used to exclude and other individuals and groups? How do local exclusionary readings of the past become woven into the texture of the everyday and normalized?

I am exploring these questions by turning everyday practices of exclusion into explicit objects of inquiry. Based on village ethnographies in regions that are frequently described as heartlands of the European right, 
I hope that the project will create a deeper understanding of the bricklayers of interior frontiers-the ordinary people supporting exclusionary ideas on the ground. They are part of a rapidly growing proportion of the population in liberal democratic societies who no longer want to adhere to the rules of the "liberal game" (Illouz, 2017 , p. 49), and openly reject its ideals of diversity, tolerance and inclusion. In recent years social scientists have started to pay increased ethnographic attention to these developments by studying right-wing activists and extremist groups such as skinheads, neo-Nazis or religious fundamentalists (Shoshan, 2016; Thorleifsson, 2018). While these studies give important insights into the affective, social and economic dynamics driving political radicalization, we know very little about the lifeworlds of ordinary people enacting exclusionary ideas on the ground. A growing number of scholars therefore emphasize the urgent need for more ethnographic studies on the social worlds of people who are not members of radical right-wing organisations, but form the everyday support base of the backlash against inclusive ideas of belonging (Hann, 2016; Hochschild, 2016; Pasieka, 2019). A more thorough understanding of what is driving this backlash is of critical importance, as it might allow us to develop answers to the fragmentation and erosion of trust marking the public realm of democratic societies. With my current research I aim to contribute to this body of knowledge by shedding light on the intersubjective processes underlying everyday boundary work. We do so by exploring the potential of history as a social glue that binds communities together and as a means of excluding others by placing them outside of a shared, communal time.

Village ethnography is a particularly helpful methodological tool for such an undertaking. While frequently portrayed otherwise, rural communities are not internally uniform microcosms. They are dynamic social and physical entities that are marked by many cleavages, ambiguities and internal incoherencies. The different people making up the social fabric of my current research site in the Austrian state of Carinthia therefore do not fit in one uniform mould that can be reduced to labels such as 'right-wing' or 'left-wing.' To understand exclusion as an intersubjective phenomenon I have to actively work with the breaks and ruptures that are part and parcel of village life. This does not just include the experiences of the bricklayers of interior frontiers, but also the perspectives and experiences of village outsiders-often people (migrants and non-migrants alike) who have been silenced or ridiculed as to not disturb the social equilibrium. In treating the village as a site of contested meanings, I can observe from up close how some people end up erecting interior frontiers while others find themselves locked outside of them.

I am still in the midst of my fieldwork, hence it is too early to give detailed ethnographic insights into the lifeworlds of the bricklayers and their counterparts. Instead, I want to use the space of this thematic issue to make a methodological point about the great degree of reflexivity this radical intersubjective approach to exclusion demands from ethnographers. Studying the bricklayers of interior frontiers involves many ethical and methodological challenges. It raises a set of dilemmas that complicate commonly accepted ideas of friendship and voice underwriting ethnographic research practices. What happens when scholars give voice to people like forty-yearold Hubert, whom I met during my fieldwork, who is convinced that if we are to prevent a future in which people like "us" are going to be replaced by Muslim migrants, we need to learn from Hitler and take some drastic decisions? My fieldwork in Carinthia has shown that the reactionary future Hubert hopes for should not be written off as an isolated, extremist derailment of one frustrated individual. His future imaginary links into much wider socio-cultural practices in this rural area that do not imagine the future as a forward movement, but hope, wish and actively work towards a world that resembles authoritarian pasts. The social reproduction of these exclusionary ideas of belonging also appear in the villages' heritage groups (Traditionsvereine). These clubs form some of the most crucial pillars of social life-not just in this rural area of Austria, but across the German-speaking Alpine region. Whilst aiming to preserve traditions, many of these clubs carry a strong exclusionary undertone: They aim to defend blood and soil from the socio-cultural infiltration of outsiders, or from the spread of cosmopolitan ideals threatening to destroy their authentic ties to the place. Is there a space in social science research for the members of heritage clubs I collaborate with, who aim for a purified 'indigenous' community of Germanic origin? And what happens to the ideal of democratized research agendas when informants use them to mingle everyday critiques of global capitalism with conspiratorial theories of a Bevölkerungsaustausch-the planned replacement of the local population by migrants? If social scientists engage with such extremist world views, do they not risk amplifying them? Given the very real suffering interior frontiers can cause, should excluders be given a voice at all? The phenomenology of exclusion I am suggesting is marked by a great dilemma that can never be fully resolved: While too much closeness to the bricklayers of interior frontiers risks normalizing their exclusionary practices, too little risks overlooking the lived realities propelling their everyday border work.

There are very few methodological guidelines that might help ethnographers work through this dilemma. The lack of research with "unlikeable" (Pasieka, 2019, p. 3) groups can partially be ascribed to the dominance of the voice paradigm in ethnographic research methodologies and researchers' reluctance to engage with political world views they cannot sympathize with. Harding (1991, p. 374) sees this reluctance directly linked to the power of the liberal intellectual tradition in Western academia that has based its self-identification as a modern, progressive force on the portrayal of the figure of the reactionary as the "repugnant cultural other" whose back- 
wardness and bigotry places him/her outside the project of modernity. Hage (2017, pp. 7-8) notes that the same liberal tradition has led to a tendency in scholars studying exclusionary practices to focus on the inconsistencies in racists' perspectives. Yet, while they have invested an enormous amount of effort in developing anti-racist critiques, people expressing exclusionary sentiments are quite happy to live with the contradictions and discrepancies they are accused of. Hage therefore suggests that we should approach racism as a practical, lived reality. It means that we need to explore the experiences and lifeworlds of people who actively participate in exclusionary practices. Approaching exclusion as a general "mode of being" (Hage, 2017, p. 13) involves asking difficult questions and engaging with individuals researchers might feel inclined to ignore. It involves following the lead of critical race scholars, who have long called for phenomenological methods that allow us to unravel the ways supremacist and racialized ideas are made and unmade in the everyday (Ahmed, 2007). It involves exploring why a growing percentage of the population come to think that in creating interior frontiers they are not doing anything questionable but simply protecting what makes their lives worth living (Hage, 2017, p. 13).

Despite the challenges such a focus on exclusion as an intersubjective phenomenon might pose, ethnographers do not need to reinvent the methodological wheel. We can build on a robust epistemological tradition that urges us to scrutinize the interplay of proximity and distance in ethnographic research encounters. It calls upon ethnographers to recognize that they are always embedded in the social processes they study, necessitating continuous balancing acts between states of closeness and distance. Empathy for our participants' struggles therefore does not have to equal sympathy with their political world views. The challenge of navigating this back and forth between states of closeness and distance has been present in all my ethnographic encounters. It has been as important in my research with refugees-for example, when Somalis in Australia I had established close ties with openly expressed their hatred for people from rival ethnic clans, or when young West African men in Switzerland who treated me like a family member simultaneously argued for the erasure of women from public life-as it is in my current village ethnography. By taking the interplay of proximity and distance seriously, we can navigate some of these challenges and overcome the danger of representing bricklayers of interior frontiers as "repugnant cultural others" (Harding, 1991) or "strangers emerging from our midst" (Illouz, 2017, p. 49). In doing so, I believe that ethnographers cannot just play an essential role in understanding the motives and causes of exclusionary practices. They can contribute to the search for a cure against the sense of discontent afflicting contemporary democracies - a fundamental erosion of trust which increasingly makes conversations across ideological divides impossible.

\section{Conclusion}

In calling for a phenomenology of exclusion, I do not intend to downplay the actions of people expressing exclusionary sentiments, or, even worse, the suffering caused in the people these sentiments are directed at. As I have tried to show in this article, by using the conceptual metaphor of the interior frontier such an approach cannot but be multidimensional. Given the impalpable, hidden ways interior frontiers are erected and defended in everyday life, and the grave impact they have on current politics of belonging, it is of immense importance to expose them as existing as real social actualities. Treating exclusion as a worldly phenomenon has a number of methodological implications. It means that ethnographers need to critically reflect on the impulse to "do good" (Fisher, 1997) through their research practices and on the paradoxes of voice this creates. It simultaneously implicates resisting the urge to explain away exclusionary cultural practices by reducing them to the effects of global processes of marginalization (Pasieka, 2019, p. 5). A phenomenology of exclusion is based on the idea that we cannot formulate a critique of border work without properly understanding its modus operandi first. It simultaneously puts the ethnographic spotlight on the people who habitually and unquestioningly inhabit a mode of being-at-home-in-the-world and those who are continuously stopped, blocked or held back from occupying this affective space. Not overhearing or silencing such intertwined experiences requires efforts on the side of the ethnographer. It requires us not to expect people to distill their experiences solely in the form of narratives or 'voices,' but to sharpen our perception to other forms of communication. It requires a methodological openness towards 'minima ethnographica' (Jackson, 1998) the small, seemingly banal modes of being determining people's everyday engagements with the world. It is important not to romanticize these everyday acts of meaning-making and misinterpret them as demonstrations of simplistic, self-contained expressions of agency or voice. By shedding light on the details of life as lived and experienced by particular individuals and groups at particular moments in time, a phenomenology of exclusion is able to show the limitations of an overly enthusiastic emphasis on the potentially emancipatory role of voice as a research tool. Instead, it unveils the 'banality of evil' (Arendt, 1963/2006) - how violent acts of boundarydrawing are often not the result of dramatic, extraordinary acts of exclusion but anchored and acted out in the course of daily life.

\section{Acknowledgments}

This work was supported by the Swiss National Science Foundation under Grant 10001A_156476 as well as by the Max Planck Society's funding scheme for independent research groups. 


\section{Conflict of Interests}

The author declares no conflict of interests.

\section{References}

Ahmed, S. (2007). A phenomenology of whiteness. Feminist Theory, 8(2), 149-168.

Alexandra, D. (2008). Digital storytelling as transformative practice: Critical analysis and creative expression in the representation of migration in Ireland. Journal of Media Practice, 9(2), 101-112.

Anderson, B. (2015). Us and them? The dangerous politics of immigration control. Oxford: Oxford University Press.

Arendt, H. (2006). Eichmann in Jersualem: A report on the banality of evil. London and New York, NY: Penguin. (Original work published 1963)

Cabot, H. (2019). The business of anthropology and the European refugee regime. American Ethnologist, 46(3), 261-275.

Chimni, B. S. (2000). Globalization, humanitarianism and the erosion of refugee protection. Journal of Refugee Studies, 13(3), 243-263.

D’Amato, G. (2012). Jenseits der Integrationspolitik als politisches Ritual? [Beyond integration policy as a political ritual?]. In J. Hangartner, U. Hostettler, A. Sieber Egger, \& A. Wehrli (Eds.), Alltag und Ritual: Statusübergänge und Ritualisierungen in sozialen und politischen Feldern. Festschrift zu Ehren von Hans-Rudolf Wicker [The everyday and ritual: Status transitions and ritualisations in social and political fields. Festschrift in honor of Hans-Rudolf-Wicker] (pp. 87-105). Zürich: Seismo.

Das, V. (1995). Critical events: An anthropological perspective on contemporary India. Delhi and New York, NY: Oxford University Press.

De Genova, N. (2013). Spectacles of migrant 'illegality': The scene of exclusion, the obscene of inclusion. Ethnic and Racial Studies, 36(7), 1180-1198.

De Genova, N. (Ed.). (2017). The borders of Europe: Autonomy of migration, tactics of bordering. Durham, NC: Duke University Press.

Fischer-Tine, H., \& Purtschert, P. (Eds.). (2015). Colonial Switzerland: Rethinking colonialism from the margins. Basingstoke: Palgrave Macmillan.

Fisher, W. F. (1997). Doing good? The politics and antipolitics of NGO practices. Annual Review of Anthropology, 26(1), 439-464.

Franks, M. (2011). Pockets of participation: Revisiting child-centred participation research. Children \& Society, 25(1), 15-25.

Hage, G. (2017). Is racism an environmental threat? Cambridge: Polity Press.

Hann, C. (2016). Overheated underdogs: Civilizational analysis and migration on the Danube-Tisza interfluve. History and Anthropology, 27(5), 602-616.

Harding, S. (1991). Representing fundamentalism: The problem of the repugnant cultural other. Social Research, 58(2), 373-393.

Hochschild, A. R. (2016). Strangers in their own land: Anger and mourning on the American right. New York, NY: New Press.

Illouz, E. (2017). From the paradox of liberation to the demise of liberal elites. In H. Geiselberger (Ed.), The great regression (pp. 49-64). Cambridge: Polity Press.

Jackson, M. (1998). Minima ethnographica: Intersubjectivity and the anthropological project. Chicago, IL: University of Chicago Press.

Jackson, M. (2019). Critique of identity thinking. London and New York, NY: Berghahn.

James, A. (2007). Giving voice to children's voices: Practices and problems, pitfalls and potentials. American Anthropologist, 109(2), 261-272.

Lamont, M., \& Molnar, V. (2002). The study of boundaries in the social sciences. Annual Review of Sociology, 28, 167-195.

Lems, A. (2018). Being here: Place-making in a world of movement. London and New York, NY: Berghahn.

Lems, A. (2019). Existential kinetics of movement and stasis: Young Eritrean refugees' thwarted hopes of movement-through-education. Soumen Anthropologi: Journal of the Finnish Anthropological Society, 44(2), 59-80.

Lems, A. (2020). Being inside out: The slippery slope between inclusion and exclusion in a Swiss educational project for unaccompanied refugee youth. Journal of Ethnic and Migration Studies, 46(2), 405-422.

Malkki, L. (1996). Speechless emissaries: Refugees, humanitarianism, and dehistoricization. Cultural Anthropology, 11(3), 377-404.

Nunn, C. (2017). Translations-generations: Representing and producing migration generations through arts-based research. Journal of Intercultural Studies, 38(1), 1-17.

O’Neill, M. (2011). Participatory methods and critical models: Arts, migration and diaspora. Crossings: Journal of Migration and Culture, 2(1), 13-37.

Oester, K., \& Brunner, B. (2015). Von Kings und Losern: Eine Performance-Ethnografie mit Schülerinnen und Schülern im transnationalisierten Stadtteil Bern West [Of kings and losers: A performance ethnography with students in the transnationalised suburb Bern West]. Wiesbaden: Springer VS.

Pasieka, A. (2019). Anthropology of the far right: What if we like the 'unlikeable' others? Anthropology Today, 35(1), 3-6.

Perl, G. (2018). Lethal borders and the translocal politics of 'ordinary people.' Anthropological Journal of European Cultures, 27(2), 85-104.

Piñeiro, E. (2015). Integration und Abwehr: Genealogie der schweizerischen Ausländerintegration [Integration and defence: A genealogy of the Swiss integration of foreigners]. Zürich: Seismo.

Ramsay, G. (2019). Time and the other in crisis: How 
anthropology makes its displaced object. Anthropological Theory. Advance online publication. https:// doi.org/10.1177\%2F1463499619840464

Reeves, M. (2014). Border work: Spatial lives of the state in rural central Asia. Ithaca, NY: Cornell University Press.

Rumford, C. (2008). Introduction: Citizens and borderwork in Europe. Space and Polity, 12(1), 1-12.

Rytter, M. (2019). Writing against integration: Danish imaginaries of culture, race and belonging. Ethnos, 84(4), 678-697.

Schapendonk, J. (2020). Finding ways through Eurospace: West African movers re-viewing Europe from the inside. London and New York, NY: Berghahn.

Schinkel, W. (2018). Against 'immigrant integration': For an end to neocolonial knowledge production. Comparative Migration Studies, 6(1). https://doi.org/ 10.1186/s40878-018-0095-1

Shoshan, N. (2016). The management of hate: Nation, affect, and the governance of right-wing extremism in Germany. Princeton, NJ: Princeton University Press.

Sossi, F. (2006). Migrare: Spazi di Confinamento e Strategie di Esistenza [Migrating: Spaces of confinement and strategies of existence]. Milan: II Saggiatore.

Stoler, A. L. (2018). Interior frontiers. In J. M. Bernstein, A. Ophir, \& A. L. Stoler (Eds.), Political concepts: A critical lexicon (pp. 1-13). New York, NY: Fordham
University Press. Retrieved from https://www. politicalconcepts.org/interior-frontiers-ann-laurastoler

Strasser, S., \& Tibet, E. E. (2020). The border event in the everyday: Hope and constraints in the lives of young unaccompanied asylum seekers in Turkey. Journal of Ethnic and Migration Studies, 46(2), 354-371.

Teitelbaum, B. R. (2019). Collaborating with the radical right: Scholar-informant solidarity and the case for an immoral anthropology. Current Anthropology, 60(3), 414-435.

Thorleifsson, C. (2018). Nationalist responses to the crisis in Europe: Old and new hatreds. London: Routledge.

Wicker, H.-R. (2009). Die neue schweizerische Integrationspolitik [The new Swiss integration policy]. In E. Piñeiro, I. Bopp, \& G. Kreis (Eds.), Fördern und Fordern im Fokus: Leerstellen des schweizerischen Integrationsdiskurses [Foster and demand: Blank spots of the Swiss integration discourse] (pp. 23-47). Zürich: Seismo.

Wikan, U. (1991). Toward an experience-near anthropology. Cultural Anthropology, 6(3), 285-305.

Yuval-Davis, N., Wemyss, G., \& Cassidy, K. (2018). Everyday bordering, belonging and the reorientation of British immigration legislation. Sociology, 52(2), 228-244.

\section{About the Author}

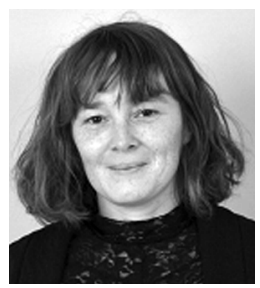

Annika Lems is Head of an independent research group at the Max Planck Institute for Social Anthropology in Halle, Germany. Prior to taking up this position she worked as a Doctoral Research Fellow at Swinburne University in Melbourne, Australia, and as a Lecturer and Postdoctoral Researcher at the University of Bern, Switzerland. Her work broadly concerns the ways people experience, negotiate and actively create place attachments in an age of rapid global transformations. 